\title{
Synthesis, Photophysical, Electrochemical and Thermal Studies of 2,3-Bithienylpyrazino[2,3-b]phenazine
}

\author{
RAJESH M. KAMBLE ${ }^{*}$, AZAM M. SHAIKH and BHARAT K. SHARMA \\ Department of Chemistry, University of Mumbai, Santacruz (East), Mumbai-400 098, India \\ kamblerm@chem.mu.ac.in
}

Received 18 March 2015 / Accepted 18 April 2015

\begin{abstract}
In this work, 2,3-bithienylpyrazino[2,3-b]phenazine [BTPP] was synthesized and its photophysical, electrochemical and thermal properties was studied and compared with 2,3-bithienylquinoxaline [BTQ] and 2,3-bithienylbenzo[g]quinoxaline [BTBQ]. The photophysical studies revealed that BTPP emit in the green region at $\lambda_{\max } 551 \mathrm{~nm}$. Electrochemical studies show that the ionization potential (HOMO) and electron affinity (LUMO) of BTPP are $-5.49 \mathrm{eV}$ and $-3.15 \mathrm{eV}$ respectively and are comparable to commonly used electron acceptor/transporter. The optical energy band gap of BTPP is $2.34 \mathrm{eV}$. Thermogravimetric analysis showed that BTPP possess good thermal stability.
\end{abstract}

Keywords: Phenazine, BTTP, OLEDs

\section{Introduction}

In last few decades there has been significant progress in the field of organic semiconductors particularly larger acenes ${ }^{1,2}$ because of their potential application in organic light-emitting diodes (OLEDs) ${ }^{3}$, organic field effect transistors (OFETs) ${ }^{4}$ and photovoltaic cells ${ }^{5}$. However most of the larger acenes ${ }^{6}$ always display $p$-type semiconducting properties (electron donor, hole transporter). $N$-type (electron acceptor, electron transporter) organic and polymer semiconductors are also needed for developing more efficient and high performance organic electronics. Heteroaromatic molecules containing imine nitrogen atoms $(\mathrm{C}=\mathrm{N})$ are promising candidates for electron transporting materials because of their valence state, high electron affinity ${ }^{7}$ and less sensitivity to oxidation and dimerization ${ }^{8}$. However very few heteroaromatics have been explored as electron transport (n-type) materials in organic electronics. Hence there is need to prepare new class of $N$-heteroacenes as an electron acceptor/transporter. BTQ and BTBQ have been used as electron transport materials to varied degree of success in organic electroluminescent devices ${ }^{9,10}$. Here we report the synthesis of BTPP and compared its photophysical, electrochemical and thermal properties with BTBQ and BTQ. 


\section{Experimental}

The BTQ, BTPP and BTBQ is synthesized by condensing 2,2'-thenoin and corresponding aromatic diamines in acetic acid. Formation of BTQ is confirmed by its melting point $143{ }^{\circ} \mathrm{C}$ $\left(\text { Lit }=143-144{ }^{\circ} \mathrm{C}\right)^{9}$. The detailed synthetic route adopted for the synthesis of BTPP and BTBQ is depicted in Scheme 1 and were characterized by spectrometry methods. Molecular structures of BTQ, BTBQ and BTPP are illustrated in Figure 1.<smiles>c1csc(-c2nc3cc4nc5ccccc5nc4cc3nc2-c2cccs2)c1</smiles>

(a)<smiles>O=C(C(=O)c1cccs1)c1cccs1</smiles>

Reaction conditions: (a) 2,3-diaminophenazine, $\mathrm{CH}_{3} \mathrm{COOH}$, Reflux, 5 h. (b) 1,2diaminonaphthalene, $\mathrm{CH}_{3} \mathrm{COOH}$, Reflux, 3 h. (c) 1,2-phenylenediamine, $\mathrm{CH}_{3} \mathrm{COOH}$, Reflux, $3 \mathrm{~h}$

Scheme 1. Synthesis of BTPP, BTBQ and BTQ<smiles>c1csc(-c2nc3cc4nc5ccccc5nc4cc3nc2-c2cccs2)c1</smiles>

BTPP<smiles>c1csc(-c2nc3cc4ccccc4cc3nc2-c2cccs2)c1</smiles>

BTBQ<smiles>c1csc(-c2nc3ccccc3nc2-c2cccs2)c1</smiles>

BTQ

Figure 1. Molecular structures of BTPP, BTBQ and BTQ

UV-Visible spectra were recorded on SHIMADZU UV-2401PC at room temperature. The excitation and emission spectra were carried out on a Perkin Elmer LS 55 Fluorescence spectrophotometer. Cyclic voltammetry studies was carried out on a computer controlled AUTOLAB PGSTATE 30 electrochemical analyzer equipped with USB electro chemical interface using GPES software version 4.9.005. Typically, a three electrode cell equipped with a glassy carbon working electrode, $\mathrm{Ag} / \mathrm{AgCl}$ (non-aqueous) reference electrode and platinum (Pt) wire as counter electrode was employed. The measurements have been carried at room temperature in anhydrous acetonitrile with tetrabutyl ammonium hexafluoro phosphate solution $(0.1 \mathrm{M})$ as supporting electrolyte with a scan rate of $100 \mathrm{mVs}^{-1}$. The potential of $\mathrm{Ag} / \mathrm{AgCl}$ reference electrode was calibrated by using ferrocene/ferrocenium redox couple which has the known oxidation potential of $+4.8 \mathrm{eV}$. Fourier transform infrared (FT-IR) spectra were recorded on a Perkin Elmer Frontier 91579. ${ }^{1} \mathrm{H}$ NMR spectra and ${ }^{13} \mathrm{C}$ NMR spectra were recorded using $\mathrm{CDCl}_{3}$ on a Bruker 300 Ultrashield spectrometer with Tetramethylsilane (TMS) as internal reference at a working frequency of $300 \mathrm{MHz}$ and $75 \mathrm{MHz}$ respectively. Elemental analysis was recorded on Euro EA elemental analyzer and Mass spectra were recorded on Thermo scientific GC-MS. 
General procedure for the synthesis of BTPP, BTBQ and BTQ

A mixture of 2,2'-thenoin $(1 \mathrm{mmol})$ and aromatic diamines $(1 \mathrm{mmol})$ was dissolved in glacial acetic acid $(10 \mathrm{~mL})$. The reaction mixture was continuously stirred at $100{ }^{0} \mathrm{C}$ for $3-5$ hours. After completion of reaction, reaction mixture is poured in cold distilled water and filtered, and washed with water. The solid thus obtained was then purified by column chromatography (eluent: $n$-hexane: chloroform ratio as 70:30) to obtain a yellow to brown solid.

\section{2,3-bithienylpyrazino[2,3-b]phenazine (BTPP)}

Yield 40\% MP: $>300{ }^{0} \mathrm{C}$. MS: $\mathrm{C}_{22} \mathrm{H}_{12} \mathrm{~N}_{4} \mathrm{~S}_{2}, \mathrm{~m} / z$ : $396.41[\mathrm{M}]^{+}$. Anal.Calcd for $\mathrm{C}_{22} \mathrm{H}_{12} \mathrm{~N}_{4} \mathrm{~S}_{2}: \mathrm{C}$ (66.64), H (3.05), N (14.13), S (16.18). Found: C (66.63), H (3.06), N (14.13), S (16.18). IR (neat, $\left.v_{\max } \mathrm{cm}^{-1}\right): 1495,1604,3026 ;{ }^{1} \mathrm{H} \mathrm{NMR}\left(\mathrm{CDCl}_{3}, 300 \mathrm{MHz}\right): \delta(\mathrm{ppm}) 7.30(\mathrm{q}, 2 \mathrm{H}, \mathrm{ArH}$, $J=1.2 \mathrm{~Hz}, 3.6 \mathrm{~Hz}), 7.41(\mathrm{~d}, 2 \mathrm{H}, \mathrm{ArH}, J=1.2 \mathrm{~Hz}, 2.7 \mathrm{~Hz}$ ), 7.66 (d, 2H, ArH, $J=1.2 \mathrm{~Hz}, 2.7$ $\mathrm{Hz}$ ), 7.89 (dd, 2H, ArH, $J=3.3 \mathrm{~Hz}, 3.6 \mathrm{~Hz}), 8.26$ (dd, 2H, ArH, $J=3.3 \mathrm{~Hz}, 3.6 \mathrm{~Hz}), 9.06$ (s, $2 \mathrm{H}, \mathrm{ArH}) ;{ }^{13} \mathrm{C} \mathrm{NMR}\left(\mathrm{CDCl}_{3}, 75 \mathrm{MHz}\right): \delta(\mathrm{ppm}) 130.01,131.64,131.97,132.08,134.57$, $139.90,142.16,145.19,154.49,162.10,165.43$.

\section{2,3-bithienylbenzo[g]quinoxaline (BTBQ)}

Yield 70\% MP: $157{ }^{0} \mathrm{C}$ Anal.Calcd for $\mathrm{C}_{20} \mathrm{H}_{12} \mathrm{~N}_{2} \mathrm{~S}_{2}$ : C (69.74), $\mathrm{H}(3.51), \mathrm{N}(8.13), \mathrm{S}$ (18.62). Found: C (69.72), H (3.53), N (8.13), S (18.62). IR (neat, $\left.v_{\max } \mathrm{cm}^{-1}\right): 1420,1520,3064 ;{ }^{1} \mathrm{H}$ NMR $\left(\mathrm{CDCl}_{3}, 300 \mathrm{MHz}\right): \delta(\mathrm{ppm}) 7.04$ (q, 2H, ArH, $\left.J=1.2 \mathrm{~Hz}, 3.9 \mathrm{~Hz}\right), 7.28$ (d, 2H, ArH, $J=0.9 \mathrm{~Hz}, 2.7 \mathrm{~Hz}), 7.50-7.55(\mathrm{~m}, 4 \mathrm{H}, \mathrm{ArH}),$,8.05 (dd, 2H, ArH, $J=3.3 \mathrm{~Hz}), 8.60$ (s, 2H, $\mathrm{ArH}) ;{ }^{13} \mathrm{C} \mathrm{NMR}\left(\mathrm{CDCl}_{3}, 75 \mathrm{MHz}\right): \delta$ (ppm) 126.80, 127.14, 127.54, 128.51, 129.17, 129.83, 134.17, 137.24, 141.79, 147.28.

\section{2,3-Bithienylquinoxaline (BTQ)}

Yield: $90 \%$ MP: $143{ }^{\circ} \mathrm{C}\left(\text { Lit }=143-144{ }^{\circ} \mathrm{C}\right)^{9}$.

\section{Results and Discussion}

\section{Photophysical properties}

The absorption and fluorescence properties of BTPP were studied in dichloromethane and toluene and compared with BTQ and BTBQ. The synthesized molecules show similar UVVis absorption spectra in both the solvents (Figure 2).

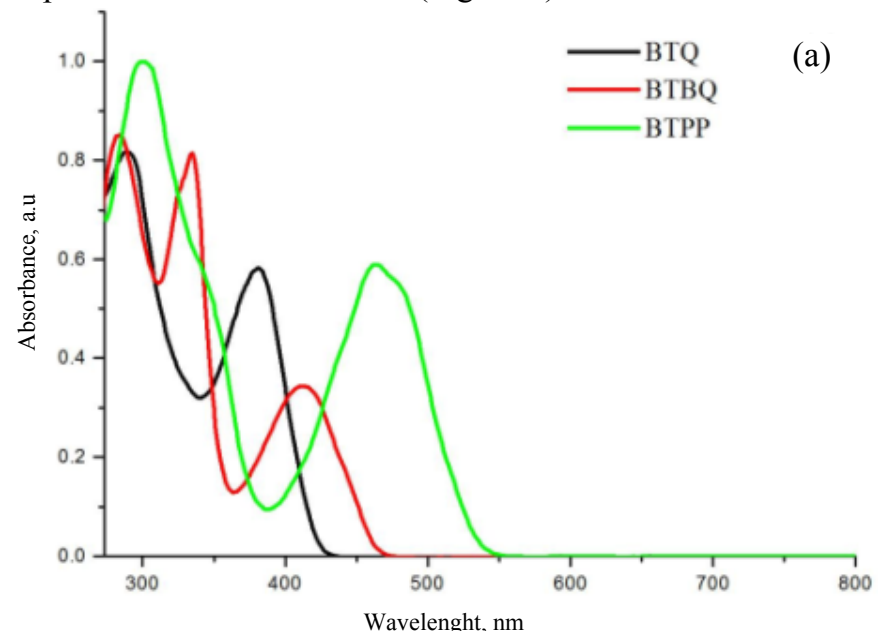




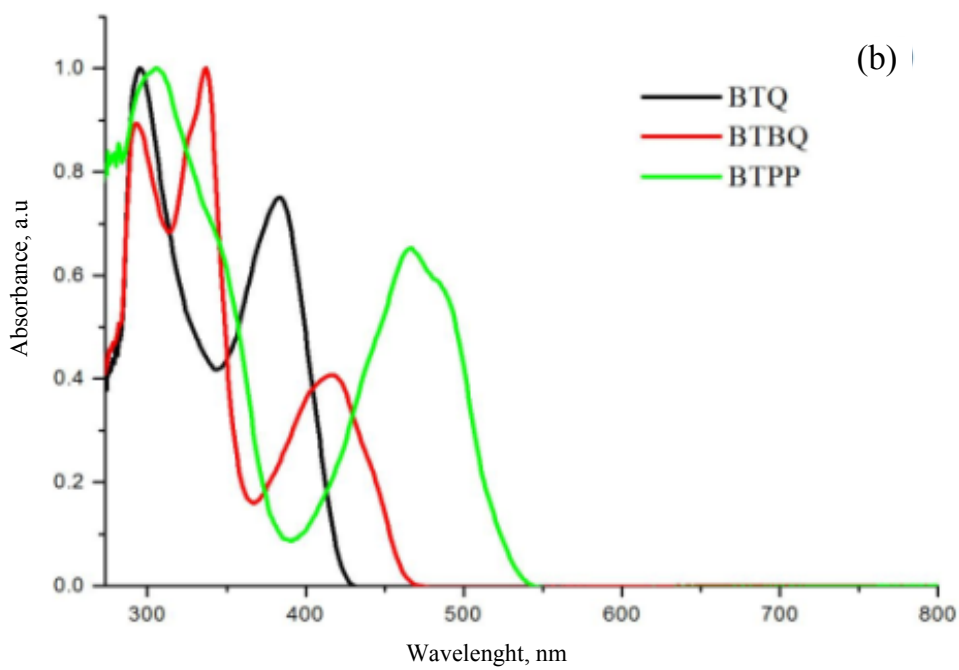

Figure 2. Absorption spectra of BTQ, BTBQ and BTPP in $\mathrm{CH}_{2} \mathrm{Cl}_{2}$ (a) and toluene (b)

The absorption spectra of BTPP reveal two major bands arising from the $\pi-\pi^{*}$ transition (300-304 nm) and lower energy charge transfer transition (461-466 nm). In addition, an $n-\pi^{*}$ transition originating from the terminal thiophene moiety is expected to appear below $300 \mathrm{~nm}$, but it is probably overlapping with the intense $\pi-\pi^{*}$ transitions.

BTPP emits in green region with $\lambda_{\text {emi }}$ at $540-551 \mathrm{~nm}$ (Figure 3 ) upon excitation at their corresponding absorption maxima in dichloromethane and toluene. On comparing emission peak of BTPP with BTQ and BTBQ it has been found that increase in conjugation along with imine $(\mathrm{C}=\mathrm{N})$ group in quinoxaline skeleton of BTPP lead to bathochromic shift of around 103 and $58 \mathrm{~nm}$ respectively.

Other basic photophysical characteristics such as the molar extinction coefficient $(\log \varepsilon)$, optical band gaps $\left(E_{g}^{\text {opt }}\right)$, Stokes shift $\left(v_{\mathrm{Abs}}-v_{\mathrm{Em}}\right)$ and fluorescent quantum yield $\left(\Phi_{\mathrm{F}}\right)$ of the molecules were determined and pertinent data is summarized in Table 1.

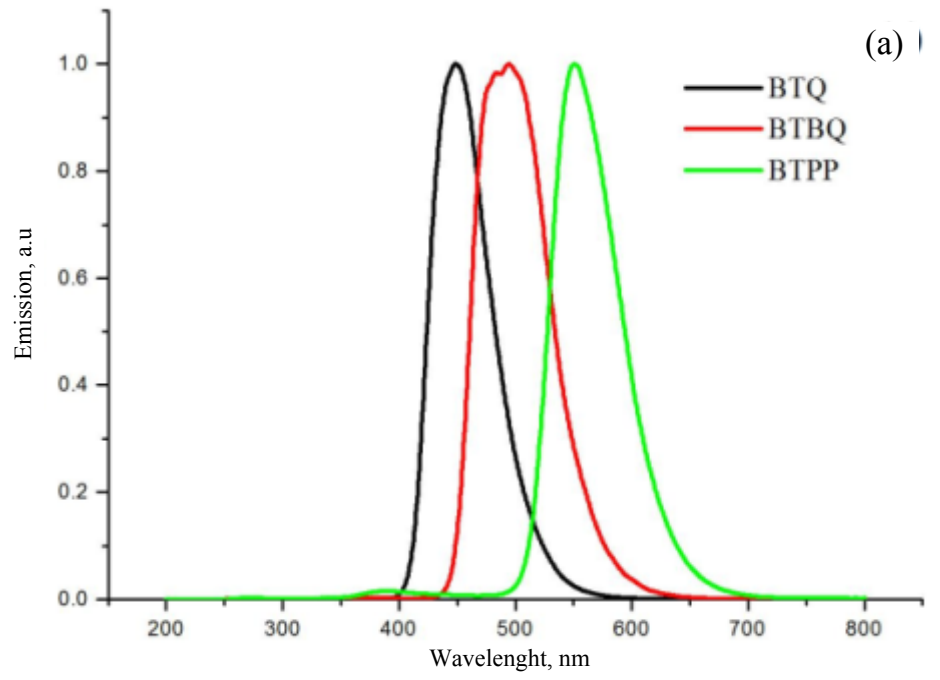




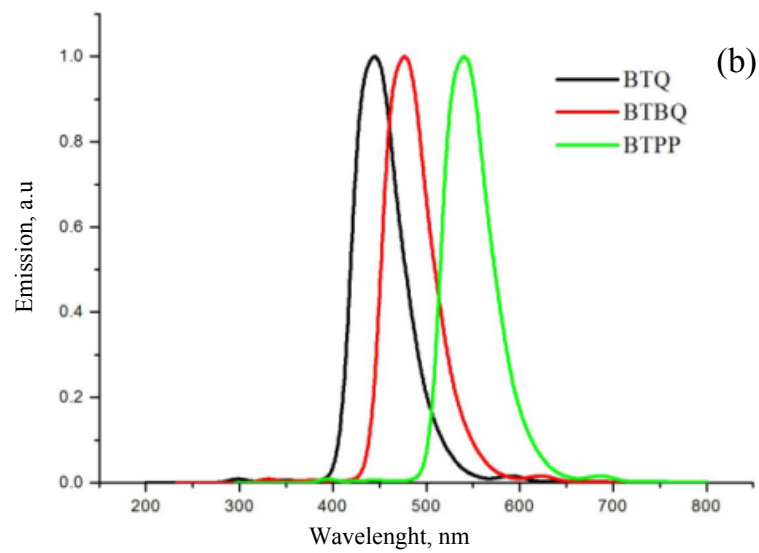

Figure 3. Emission spectra of BTQ, BTBQ and BTPP in $\mathrm{CH}_{2} \mathrm{Cl}_{2}$ (a) and toluene (b)

Table 1. Photophysical data of BTQ, BTBQ and BTPP

\begin{tabular}{|c|c|c|c|c|c|c|c|c|}
\hline \multirow[b]{2}{*}{ Compd } & \multicolumn{2}{|c|}{$\lambda_{\text {abs }}, \mathrm{nm}^{\mathrm{a}}$} & \multicolumn{2}{|c|}{$\lambda_{\mathrm{emi}}, \mathrm{nm}^{\mathrm{a}}$} & \multirow{2}{*}{$\log \varepsilon^{b}$} & \multirow{2}{*}{$\begin{array}{c}E_{g}^{o p t} \\
(\mathrm{eV})^{\mathrm{c}}\end{array}$} & \multirow{2}{*}{$\begin{array}{l}\text { Stoke } \\
\text { shift }^{d}\end{array}$} & \multirow{2}{*}{$\Phi_{F}^{e}$} \\
\hline & $\mathrm{CH}_{2} \mathrm{Cl}_{2}$ & toluene & $\mathrm{CH}_{2} \mathrm{Cl}_{2}$ & toluene & & & & \\
\hline & 290 & & 44 & & & & 16741 & 0.2 \\
\hline BTB & $82,335,411$ & 94,33 & 493 & 47 & 4.5 & 2. & 58 & 0.2 \\
\hline ВТРP & 300,461 & 304,466 & 551 & 540 & 4.297 & 2.34 & 20461 & 0.20 \\
\hline
\end{tabular}

${ }^{a}$ Recorded in $10^{-5} \mathrm{~mol} \mathrm{~L}^{-1}$ in $\mathrm{CH}_{2} \mathrm{Cl}_{2}$ and toluene. ${ }^{b}$ Extinction coefficient $\left(\mathrm{L}^{-1} \mathrm{~mol}^{-1} \mathrm{~cm}^{-1}\right)$ measured in $\mathrm{CH}_{2} \mathrm{Cl}_{2} .{ }^{C}$ Optical bandgap estimated from the optical edge of solution form $\left(\mathrm{E}_{\mathrm{g}}{ }^{\mathrm{opt}}=1240 / \lambda_{\text {opt edge }}\right) \mathrm{eV}$.

${ }^{d}$ Stokes shift calculated from absorption and emission wavelength observed in solution form. ${ }^{e}$ Quantum yield with reference to $\mathrm{Alq}_{3}\left(\Phi_{F}=0.16\right.$ in benzene)

\section{Electrochemical properties}

Electrochemical properties of the synthesized molecules were studied by cyclic voltammetry. On anodic sweep BTBQ and BTQ shows one irreversible wave corresponding to one electron oxidation of thiophene segment. No wave was observed for the BTPP on anodic sweep. However on cathodic sweep BTBQ and BTQ show one reversible wave corresponding to one electron reduction of quinoxaline segment and BTPP shows one irreversible wave suggesting stable one radical anion formation ${ }^{11}$. The reduction potential of BTPP is $-1.26 \mathrm{~V}$ which is lower than BTQ and BTBQ. The HOMO and LUMO levels of BTPP are $-5.76 \mathrm{eV}$ and -3.15 $\mathrm{eV}$ respectively. Thus BTPP may acts as electron acceptor/transporter material since it has low reduction potential and its LUMO value is above $3.0 \mathrm{eV}^{12}$. The observed parameters are reported in Table 2 and cyclic voltammogram is displayed in Figure 4a.

Table 2. Electrochemical and thermal data of BTQ, BTBQ and BTPP

\begin{tabular}{ccccccc}
\hline Compd & $E_{a x}^{\text {peak }}(\mathrm{V})$ & $E_{\text {red }}^{\text {peak }}(\mathrm{V})$ & $\mathrm{HOMO}^{\mathrm{a}}(\mathrm{eV})$ & $\mathrm{LUMO}^{\mathrm{b}}(\mathrm{eV})$ & $\mathrm{T}_{\mathrm{m}}{ }^{0} \mathrm{C}^{\mathrm{c}}$ & $\mathrm{T}_{\mathrm{d}}\left({ }^{0} \mathrm{C}\right)^{\mathrm{d}}$ \\
\hline BTQ & 1.76 & -1.69 & -5.734 & -2.717 & 143 & $262(283)$ \\
BTBQ & 1.62 & -1.39 & -5.753 & -3.033 & 157 & $293(321)$ \\
BTPP & & -1.26 & -5.496 & -3.156 & $>300$ & $190(221)$ \\
\hline
\end{tabular}

${ }^{a}$ HOMO energy calculated from $E_{\text {HOMO }}=$ Optical bandgap $+L U M O,{ }^{b}$ LUMO energy calculated $E_{L U M O}=-\left[E_{\text {red }}\right.$ peak $\left.-E_{\text {red }}\left(F c / F^{+}\right)+4.8\right] \mathrm{eV} .{ }^{c}$ Melting point (Open capillary Method). ${ }^{d}$ Decomposition temperature [5\% and $10 \%$ (in parentheses) weight loss] derived by TGA. 

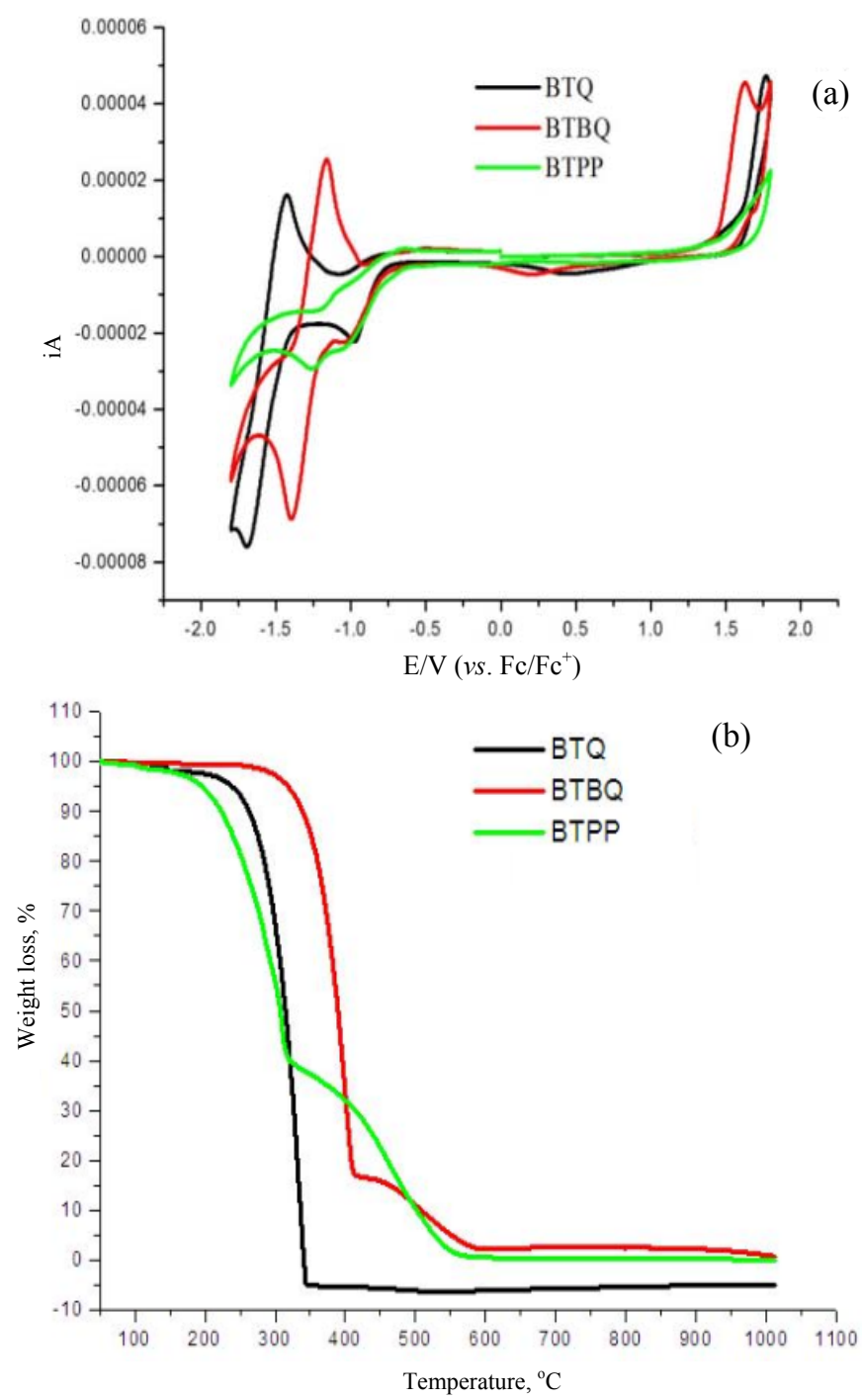

Figure 4. Cyclic voltammogram (a) and TGA thermogram (b) of BTQ, BTBQ and BTPP under nitrogen atmosphere

\section{Thermal properties}

Despite being relatively low molecular weight BTTP show amorphous nature and good thermal stability. The thermal stability of BTQ, BTBQ and BTPP (Figure 4b) was determined by Thermogravimetric analysis (TGA) at the temperature range of $30-1000{ }^{\circ} \mathrm{C}$ at a constant heating rate of $10{ }^{\circ} \mathrm{C} \mathrm{min}^{-1}$ under nitrogen atmosphere. While the melting point of target molecules were less approximately determined by open capillary method. The decomposition temperature corresponding to $5 \%$ and $10 \%$ weight loss of BTPP are $190{ }^{\circ} \mathrm{C}$ and $221{ }^{\circ} \mathrm{C}$ (Table 2) respectively. However decomposition temperature of BTBQ and BTQ is slight higher than that of BTPP. 


\section{Conclusion}

We have synthesized BTPP and compared its optoelectronic properties with BTQ and BTBQ. BTPP emits in green region in solution with good electron affinity. The above studies indicate that the increase in conjugation along with imine $(\mathrm{C}=\mathrm{N})$ group in quinoxaline skeleton of BTPP significantly lead to increase in electron affinity and decrease in band gap compared with BTQ and BTBQ. Hence based on above studies BTPP may act as electron acceptor/transporter material.

\section{Acknowledgement}

The authors are greatly thankful to Micro analytical Laboratory, Department of Chemistry and University of Mumbai for providing research facilities.

\section{References}

1. Anthony J E, Chem Rev., 2006, 106(12), 5028-5048; DOI:10.1021/cr050966z

2. Bendikov M, Wudl F and Perepichka D F, Chem Rev., 2004, 104(11), 4891-4896; DOI:10.1021/cr030666m

3. Duong H M, Yoga D, Hieu M D, Zhang H, Boey F, Sun X.W and Wudl F, J Mater Chem., 2010, 20, 8167-8170; DOI:10.1039/C0JM01460E

4. Duong H M, Bendikov M, Steiger D, Zhang Q, Sonmez G, Yamada J and Wudl F, Org Lett., 2003, 5(23), 4433-4436; DOI:10.1021/o1035751v

5. Gorodetsky A A, Cox M, Tremblay N J, Kymissis I and Nuckolls C, Chem Mater., 2009, 21(18), 4090-4092; DOI:10.1021/cm9016134

6. Watanable M, Chang Y J, Liu S W, Chao T H, Goto K, Yuan, Md M I C H, Tao Y T, Shinmyozu T and Chow T, J Nat.Chem. 2012, 4, 574-578.

7. Winkler $\mathrm{M}$ and Houk K N, $J$ Am Chem Soc., 2007, 129(6), 1805-1815; DOI:10.1021/ja067087u

8. Appleton A L, Brombosz S M, Barlow S, Sears J S, Bredas J L, Marder S R and Bunz U H F, Nat Commun., 2010, 1, 91.

9. Han M H, Song H L, Lee T H, Lee J Y, Moon D K and Haw J R, Synthetic Metals, 2012, 162(24), 2294-2301; DOI:10.1016/j.synthmet.2012.11.004

10. Shitagaki S, Yamazaki H and Seo S, PCT Int. Appl. 2004, WO 2004043937 A1 20040527.

11. Armand J, Boulares L, Bellec C and Pinson J, Can J Chem., 1982, 60(22), 27972803; DOI:10.1139/v82-402

12. Newmann C R., Frisbie C D, da Silva Filho D A, Bredas J, Ewbank P C and Mann K R, Chem Mater., 2004, 16(23), 4436-4451; DOI:10.1021/cm049391x 